\title{
Dərin Neyron Şəbəkələrin Çoxnüvəli Qrafik Prosessor Platformasinda Öyrədilməsi
}

\author{
Kamil Ayda-zadə ${ }^{1}$, Elşən Mustafayev ${ }^{2}$, Samir Rüstəmov ${ }^{3}$ \\ ${ }^{1,2}$ AMEA İdarəetmə Sistemləri İnstitutu, Bak1, Azərbaycan \\ ${ }^{3}$ ADA Universiteti, Bak1, Azərbaycan \\ ${ }^{1}$ kamil-aydazade@rambler.ru, ${ }^{2}$ elshan.mustafayev@gmail.com, ${ }^{3}$ samir.rustamov@gmail.com
}

\begin{abstract}
Xülasə- Məqalədə dərin neyron şəbəkələrin çox prosessorlu qrafik GPU və ənənəvi CPU-əsaslı platformalarında öyrədilməsi məsələsinə baxılmışdır. Test məsələ olaraq MNIST (Modified National Institute of Standards and Technology) verilonlər bazasında əlyazma rəqəmlərinin tanınması götürülmüşdür. Dərin neyron şəbəkənin verilmiş məsələ üçün hər iki platformada nəticələri müqayisəli təhlil edilmişdir.
\end{abstract}

Açar sözlor-dorin neyron şəbəkə, roqəmlorin tanınması, GPU, CUDA, Tensorflow, MNIST

\section{GİRIŞ}

Son zamanlar surətlərin tanınmasında (təsvirlərin klassifikasiyası və klasterizasiyası, səs və qrafik məlumatların tanınması və s.) dərin neyron şəbəkələrin istifadəsi geniş yayılıb. Bu növ şəbəkələrin qurulması və öyrədilməsi üçün müxtəlif proqram sistemləri işlənilmişdir - Tensorflow, Caffe, Torch, Teano. Bu paketlərin köməyi ilə dərin neyron şəbəkələrin məsələlərini asanlıqla həll etmək olur. Lakin dərin neyron şəbəkələrin inkişafının ən böyük məhdudiyyəti yüksək hesablama xərcləridir. Bu məhdudiyyətlərin aradan qaldırması yollarından biri kimi çoxnüvəli qrafik prosessorlardan istifadə nəzərdə tutulur. Belə həllərin arasında NVIDIA şirkətinin CUDA (Compute Unified Device Architecture) texnologiyas1 xüsusi yer tutur. CUDA texnologiyası çoxnüvəli qrafik prosessorların (GPU) nüvələrini paralel istifadə etməklə elmi və mühəndis hesablamalarını müasir klaster sistemləri səviyyəsində sürətləndirir [1].

Təqdim etdiyimiz məqalənin məqsədi Tensorflow [2] sistemində CUDA texnologiyasını istifadə etməklə əlyazma rəqəmlərinin dərin neyron şəbəkə vasitəsi ilə tanınması məsələsində imkan və xüsusiyyətlərin araşdırılmasıdır.

\section{CUDA MÜHITIINDӘ PARALEL HESABLAMALARIN APARILMASI}

NVIDIA qrafik sürətləndiricilərində səkkizinci seriyadan başlayaraq CUDA paralel arxitekturası reallaşdırılıb. $\mathrm{Bu}$ texnologiya qeyri-qrafik hesablamaları aparmaq üçün xüsusi proqram interfeysini təqdim edir [3].

Məntiqi cəhətdən CUDA texnologiyasını dəstəkləyən qrafik prosessora çoxnüvəli prosessorlar toplusu kimi baxmaq olar. Belə videoçiplərin əsas hesablama blokları multiprosessorlardan ibarətdir. Onlar səkkiz nüvədən, bir-neçə min 32-bitlik registrdən, 16 kbayt ümumi yaddaşdan, tekstur və konstant keşdən ibarətdir (şək.1).

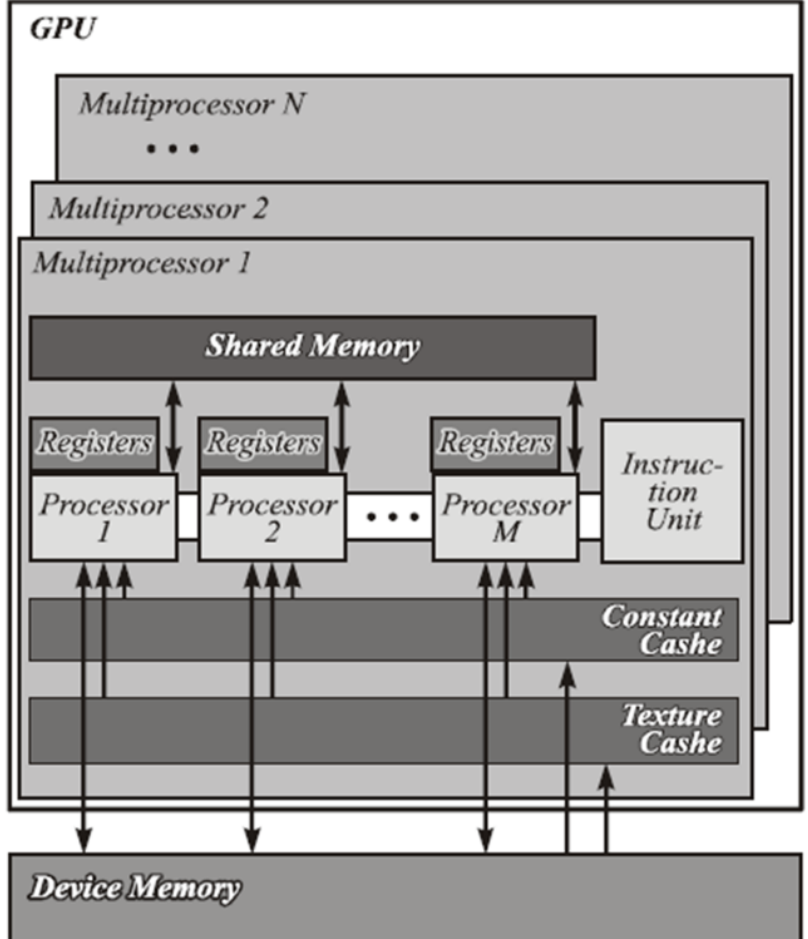

Şəkil 1. Video kartın multiprosessor toplusu və yaddaş növləri.

CPU və GPU arasında əlaqə qurmaq üçün qlobal yaddaş istifadə olunur və məlumatların ötürülməsi sürəti yalnız PCI Express buraxma imkanı ilə məhdudlaşır. CUDA texnologiyasının proqramlaşdırma nöqteyi-nəzərindən əsas mahiyyoti paralel olaraq eyni növ hesablamaların vahid iyerarxik hesablama axınına keçməsidir. Belə çoxsaylı hesablama axınları bir multi-prosessorda yerinə yetirilir və ümumi yaddaş vasitəsi ilə qalan multi-prosessorlarla sinxronlaşırlar.

\section{EKSPERIMMENTLӘRINN NOTİCӘLӘRİ}

Qrafik prosessorların dərin neyron şəbəkələrində hesablama üstünlüklərini yoxlamaq üçün NVIDIA Tesla K40 qrafik sürətləndiricidən istifadə olunub. Bu video sürətləndiricinin göstəriciləri aşağıdakılardır:

- Maksimal hesablama gücü - 4.29 Tflops

- Yaddaş sürəti - $288 \mathrm{~GB} / \mathrm{s}$ 
- Yaddaş həcmi - 12GB

Təcrübə zamanı istifadə olunan platformanın göstəriciləri:

- Prosessor - İntel Core i3-3.3GHz;

- Operativ yaddaş - 4GB;

- Qrafik sürətləndirici - NVIDIA Tesla K40;

- Proqram təminat:

$\checkmark \quad$ Windows 7 64-bit Professional;

$\checkmark$ Python 3.5.2;

$\checkmark$ Tensorflow 1 GPU support;

$\checkmark$ CUDA Toolkit 8.0.

Eksperimentlərdə əlyazma verilənlər bazası kimi məşhur MNIST [4] bazasından istifadə olunub. Bu verilənlər bazası 55000 öyrədici və 5000 test nümunələri olan əlyazma rəqəm təsvirlərdir. Bütün təsvirlər ölçü baxımından normallaşdırılıb və $28 * 28$ ölçüyə gətirilmişdir. Təsvirlərdəki piksellər 0-255 arasında qiymotlər alır. Burada 0-qara, 255-ağ rəngi göstərir, arada olan qiymətlər isə boz rəngin çalarlarını bildirir (şək. 2).

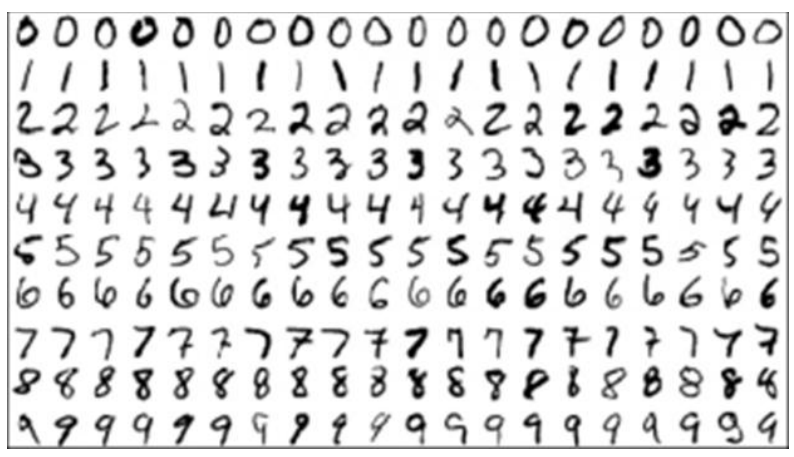

Şəkil 2. MNIST əlyazma nümunələri.

Təcrübədə iki müxtəlif strukturlu neyron şəbəkələrdən istifadə olunub:

1. Dörd laya malik tam əlaqələndirilmiş şəbəkə - [5]:

$\checkmark$ giriş layı $28 \times 28=784$

$\checkmark$ 1-3 gizli lay: 500 neyron

$\checkmark$ çıxış lay: 10 neyron

2. Bürünmə şəbəkəsi - Convolutional Network (CN) [6]:

$\checkmark$ giriş layı : 28x28=784

$\checkmark$ 1-ci gizli lay:

- Bürünən lay: 1giriş, 32 çıxış təsviri, $5 \times 5$ ölçülü nüvə

- MaxPool alqoritmi

$\checkmark \quad$ 2-ci gizli lay:

- Bürünən lay: 32 giriş, 64 çıxış təsviri, $5 \times 5$ ölçülü nüvə
- MaxPool alqoritmi

$\checkmark \quad$ 3-cü lay - tam əlaqələndirilmiş

- giriş layı - 1024 neyron

- çıxış layı - 10 neyron.

Öyrətmə üsulu olaraq Adam optimallaşdılma üsulu istifadə edilmişdir.

Cədvəl 1-dən göründüyü kimi, qrafik prosessorlardan istifadə neyron şəbəkələrin öyrədilməsini əhəmiyyətli dərəcədə sürətləndir.

CəDVӘL I. NEYRON ŞəBӘKӘLӘRİN ÖYRӘTMӘ NӘTICəLӘRININ MÜQAYISOSİ

\begin{tabular}{|c|c|c|c|c|}
\hline \multirow{2}{*}{$\begin{array}{c}\text { Neyron } \\
\text { şbəkə }\end{array}$} & \multicolumn{2}{|c|}{ Təcrübə platforması } & \multicolumn{2}{c|}{ Tanıma noticəlori } \\
\cline { 2 - 5 } & $\boldsymbol{C P U}$ & $\boldsymbol{C P U}+\boldsymbol{G P U}$ & $\begin{array}{c}\text { Öyrotmə } \\
\text { baza }\end{array}$ & $\begin{array}{c}\text { Test } \\
\text { baza }\end{array}$ \\
\hline $\mathrm{MN}$ & 6 dəq $31 \mathrm{~s}$. & 2 dəq $25 \mathrm{~s}$. & $91,6 \%$ & $89,7 \%$ \\
\hline $\mathrm{CN}$ & $47 \mathrm{dəq} 5 \mathrm{~s}$. & 6 dəq $21 \mathrm{~s}$. & $99,6 \%$ & $98,2 \%$ \\
\hline
\end{tabular}

\section{ӘDӘBIYYYAT}

[1] M. Fatica. CUDA for High Performance Computing: materials of HPCNA Workshop 3 ,January, 2009

[2] https://www.tensorflow.org/

[3] CUDA Toolkit | NVIDIA Developer https://developer.nvidia.com/cudatoolkit

[4] Y. Le Cun. The MNIST database of handwritten digits // MNIST handwritten digit database, Yann LeCun and Corinna Cortes. [2009]. http://yann.lecun.com/exdb/mnist

[5] К.Р.Айда-заде, Э.Э.Мустафаев. Об оптимизации параметров нейронной сети на этапе ее обучения / Труды Республиканской научной конференции «Современные проблемы информатизации, кибернетики и информационных технологий», ", том I, Баку, 2003, c. 118-121

[6] Y.Le Cun, Y.Bengio. Convolutional networks for images, speech, and time-series. In M. A. Arbib, editor, The Handbook of Brain Theory and Neural Networks. MIT.

Bu iş Azarbaycan Respublikasının Prezidenti yanında Elmin İkişafı Fondunun maliyya yardımı ilo yerino yetirilmişdir - 5-ci mobillik qrant. 